\title{
IMPACT OF PUBLIC EXPENDITURE ON EDUCATION BY LEVEL OF EDUCATION ON ECONOMIC GROWTH IN CAMEROON
}

\author{
NJOUPOUOGNIGNI Moussa \\ Enseignant-chercheur des Universités, Department of economics-University of Douala \\ DOI: 10.46609/IJSSER.2020.v05i12.004 URL: https://doi.org/10.46609/IJSSER.2020.v05i12.004
}

\begin{abstract}
This study aims to assess the impact of public spending on education by level of study on economic growth in Cameroon. Although public spending on education is qualitatively and quantitatively efficient, the effect of their distribution by level of education on growth rate in Cameroon's economy has been tested econometrically. The results show a mixed impact of this distribution on economic growth. While all levels of education have a positive effect on economic growth, public spending on primary, secondary and higher education is found to have differentiated effects, negative for primary education and positive for secondary and higher education. These results plead in favor of a deep readjustment of the distribution structure of public education spending in Cameroon. It is essential to allocate more public resources for primary education and to maintain the level of public spending on education in secondary and higher education.
\end{abstract}

Keywords: education by level, public expenditure, economic growth, Cameroon

Résumé : Ce papier se propose d'apprécier l'impact des dépenses publiques d'éducation par niveau d'études sur la croissance économique au Cameroun à travers une étude économétrique. Bien que les dépenses publiques d'éducation soient qualitativement et quantitativement efficientes, il a été testé économétriquement l'effet de leur répartition par niveau d'études sur le taux de croissance de l'économie du Cameroun. Les résultats ont montré l'impact mitigé de cette répartition sur la croissance économique. Pendant que tous les niveaux de scolarisation agissent favorablement sur la croissance économique, on trouve que les dépenses publiques d'éducation du primaire, secondaire et du supérieur ont des effets différenciés, négatif pour le primaire et positif pour le secondaire et le supérieur. Alors, ces résultats plaident en faveur d'un réajustement profond de la structure de répartition des dépenses publiques d'éducation au Cameroun. Il s'avère indispensable d'allouer davantage des ressources publiques en faveur de l'éducation du niveau primaire et du maintien du niveau des dépenses publiques d'éducation dans l'enseignement secondaire et supérieur. 


\section{International Journal of Social Science and Economic Research}

ISSN: $2455-8834$

Volume:05, Issue:12 "December 2020"

Mots clés : Education par niveau, Dépenses publiques, Croissance économique, Cameroun.

\section{Introduction}

Developing countries have generally seen an improvement in their economic situation over the last decade. The evolution of the Human Development Index (HDI) over nearly 30 years shows that all regions and all categories of human development have made considerable progress. The value of the global HDI has increased from 0.598 in 1990 to 0.728 in 2017, say an increase of almost $21.7 \%$. Globally, we have a high lifespan, we have been in school and our incomes are higher. The average lifespan has increased by seven years since 1990, and more than 130 countries have achieved universal primary schooling education (United Nations Development Programme, 2018).

In Cameroon, after recording growth of 4.5 percent in 2016, growth fell to $3.2 \%$ in 2017 , mainly due to a sharp decline in oil production despite the gradual rebound in international prices. Inflation remained low, below $1 \%$ per annum. The economy resisted in 2017 to the various exogenous shocks, for instance the Nigeria and the Central African Republic border security crisis, the North-West and South-West socio-political crises as well as the fall of the raw material prices. The gradual start-up of several major infrastructural projects as well as the abort acceleration of construction work for the 2019 African Cup of Nations and the implementation of the Three-Year Emergency Plan 2015-2017 for the acceleration of economic growth in Cameroon, have helped to sustain demand and improve the supply of certain factors of production (IMF,2018). In terms of public spending on education, it has been steadily increasing from $13.8 \%$ of government expenditure, i.e. $3 \%$ of GDP in 2013 to $14.11 \%$ of the total budget in 2018.

Indeed, based on the principles of equality, social justice and equity, and taking into account the results of the evaluation of private and social rates of return of the different levels of education as well as positive externalities related to education; the international institutions agreement encourage countries to give particular priority to the success of a universal primary education. In order to do so, it recommended that they carry out an allocation of public resources to the different levels of education according to a new standard. This, among other reasons in the name of equity and the fact that at the level of education the expected public rates of return to primary education are higher than those for other levels of education. It is recommended that countries choose primary education as a "priority of priorities" by devoting the major part of their resources to it $50 \%$ of the national budget for education in addition to international aid to the sector), and to move towards a reduction in funding for higher and secondary education.

These proposals for resource allocation are certainly supported by a theory and results of empirical studies. However, these arguments have not, so far, been unanimously accepted by all 


\section{International Journal of Social Science and Economic Research}

ISSN: $2455-8834$

Volume:05, Issue:12 "December 2020"

specialists in the educational domain. Disagreement sometimes focuses on the importance and the realization of the cost-effectiveness assessed for each level of education, the methodologies adopted for the analyses, the quality of the data as well as assumptions that are too theoretical and not realistic enough. As a result, one may question the real improvement that could provide a policy based on such uncertain foundations. In view of the requirements of rapid development brought about by globalization and the economy knowledge, there is a temptation to be dubious about the effectiveness of the educational policies currently being implemented (based on a substantial increase in funding for primary education at detriment of other levels) in Developing Countries such as Cameroon. The recommendation strategies for allocating financial resources in the different educational levels are not without problems. The choice of the 'all-primary' approach sometimes advocate, or a solution aimed at higher education and R\&D only don't always seem to be optimal. With this in mind, we asked ourselves the question: What is the impact of public expenditure on education at different levels on economic growth in Cameroon?

The question of whether or not the State should further finance the education system remains an important concern. The distributive function of the State is fundamental to justify its intervention in the education sector. With regard to market imperfections, a number of them can be corrected by public intervention. Roemer (1998), thinks that individuals have equal opportunities if their earnings expectations depend only on their efforts and not on their own characteristics or circumstances for which they cannot be held responsible. In the education sector, this condition will not be met without public intervention by applying the principle of reparation, which must be applied to the least favored categories (Liberal or Classic). Given the desirability of State action to finance the education system, some authors have questioned the impact of public expenditure on education by level of education on economic growth. These authors who have been interested in this type of analysis come to divergent conclusions. Some conclude that the most advanced countries (close to the "technological frontier" represented by the USA) should give priority to the financing of higher education. On the other hand, countries far from the technological frontier (the developing countries) give priorities to the financing of primary and secondary education (Aghion \& Cohen, 2004; Berthélemy \& Rest off, 2002). Others, on the other hand, think that the emphasis should be placed on Secondary and Higher Education in developing countries such as Cameroon (Aghion \& Cohen, 2004; Pellier, 2002).

Within the framework of the Education for All (EFA) Sustainable Development Goals (SDGs), stated by the United Nations $(2015)^{1}$ in its goal $n^{\circ} 4$, is that primary education should be considered an integral part of the education system and as a "priority of priorities" in developing

\footnotetext{
${ }^{1}$ The 25th of September 2015, 193 leaders in the world met during the General Assembly of the United Nation and came out with 17 objectives in order to attain 3 super objectives by 2030 that is *put an end to extreme poverty, *fight against injustice and inequality and to *Manage the problem of climate change.
} 


\section{International Journal of Social Science and Economic Research}

ISSN: $2455-8834$

Volume:05, Issue:12 "December 2020"

countries. In this case, $50 \%$ of total national resources for education must be directed towards primary education. The strategies recommended for allocating financial resources in the different educational levels are not without their problems. The choice of the «all-primary» which they sometimes advocate, or a solution aimed at higher education and R\&D only, doesn't always seem to be optimal. In either case, one can fall into a corner solution which in economic and social terms, is not acceptable. It therefore seems relevant to ask the question: What is the impact of public spending on education by level of education on economic growth in Cameroon? This study is of twofold interest: A theoretical interest: A Contribution to the debate on impact of public expenditure on education of the different levels of education on economic growth. A practical interest: this work makes a modest contribution to the driving of education policy in Cameroon, by providing elements that can enable an optimal allocation of resources for financing the different levels of education in Cameroon. Looking at education from a disaggregated angle, it also proves more fruitful for the policy maker as it indicates how resources should be allocated among the different levels of education.

\section{1- Literature review on the link between education spending and growth}

Several economists have addressed the link between education and economic growth. The question of spending by level and growth remains unresolved. The work already carried out will enable us to report on what has already been done on the subject. Solow's (1957) model has given rise to many interpretations, including those related to the role of education. Schultz (1962) emphasizes the importance of the quality of the labor force in the process of economic development, particularly with regard to the productivity of agricultural labor. Becker (1962) really introduces Smith's (1776) intuition into formal economic analysis, investment in human capital becomes analogous to investment in physical capital. This investment in human capital is supposed to increase individual productivity and wages. By aggregation, this investment contributes to growth. Investment in human capital is therefore a combination of time and other material resources to increase the stock of human capital.

Weisbrod (1932) was the first to analyze the positive externalities of education. He argued that these effects provide ample justification for state intervention in education. These effects benefit to the family and neighbors of the education beneficiary, to the colleagues at work and society in general. This human capital theory has undergone a rich heuristic development in growth analysis. Theoretical and empirical work (Arrow, 1962 and Nelson and Phelps, 1966) on the link between human capital and growth helped to create a kind of consensus among policy-makers in the 1960s in favor of a massive expansion of publicly funded education systems. Subsequently, the level of public expenditure on education and the number of young people has increased. 


\section{International Journal of Social Science and Economic Research}

ISSN: $2455-8834$

Volume:05, Issue:12 "December 2020"

The special feature of investment in human capital is that it fully involves the individual who makes it. Ben - Porath (1967) has highlighted the first rigorous solution to the problem of the optimal choice of educational investments over the life cycle. This solution is known as the BenPorath effect. The central argument of Ben-Porath (1967) is that at each period of time the individual invests in human capital according to the costs and benefits that arise at that stage of life. He behaves like a firm in the face of given price conditions: investment in human capital is described using a production function and will be realized until its marginal cost equals the present value of marginal earnings. The earning life cycle appears as the result of a succession of optimal human capital investment decisions in each period. This effect is generally used as the theoretical basis for Mincer's (1974) earning function, which effectively captures, for an individual, the education-wage relationship (Hanchane and Moullet, 1999). However, when seeking to measure the return on public investment in education, it is assumed that investment in human capital also comes from a collective decision and thus, according to the Ben-Porath effect, an increase in the life expectancy of the population would reflect a higher return on investment in education and consequently an increase in the level of education (Leker and Ponthière, 2012). This effect assumes a positive correlation between life expectancy and educational attainment. Leker and Ponthière (2012) find this positive correlation across a set of 17 OECD countries.

One of the spectacular developments in human capital theory has been on the revival of so-called "endogenous growth theories". The old growth theories considered that growth has exogenous determinants (generally the growth of the active population and that of technical progress). They postulate that growth is not self-sustaining and is not a cumulative process. On the contrary, the study of divergences between growths in different regions of the world seems to show that growth is not a natural phenomenon. To integrate this economists have built the theories of endogenous growth. These theories will explain the maintenance of a self-sustaining growth rate by endogenizing the actors' choices in terms of investment in human capital. The proponents of the endogenous growth theory reject the primordial role of the state, but accept that the state should promote growth over a long period of time. The question is not whether or not the state should intervene in economic activity, but how and to what extent it can intervene. In 1990, Barro demonstrated that public expenditure is directly productive and should therefore be considered as one of the factors of the production function. The contribution of the public sector to growth includes public spending on education and research and development, but also spending on other public infrastructures. Like other accumulations, this expenditure has a cumulative effect: it increases growth by widening the tax base, leading to an increase in public revenue which is a factor of growth. This theory demonstrates the need to maintain public investment in a difficult economic climate and raises the question of public intervention in the economic sphere. As a result, since the State has an economic activity of its own which is useful 


\section{International Journal of Social Science and Economic Research}

ISSN: $2455-8834$

Volume:05, Issue:12 "December 2020"

to the community, it is possible to identify theoretically the behavior of the State in terms of the allocation of its resources in the long term, particularly in the education sector where its intervention is proving increasingly indispensable. Barro and Sala-i-Martin (1995) used a large sample of countries over the period 1965-1985 to regress the average growth rate on several macroeconomic variables, including the share of public expenditure on education in GDP. Their results show that public expenditure on education has a positive and significant effect on growth: an increase of $1.5 \%$ in the ratio of public expenditure on education to GDP would have increased the average growth rate by $0.3 \%$ per year during the period 1965-1985.

Aghion and Howitt (2010), show that significant correlations between public spending on education and growth can be found by decomposing the public education expenditure in different levels. This approach is in line with the contribution Nelson and Phelps (1966), whose human capital stock is the principal source of the growth. Nelson and Phelps (1966), and Benhabib and Spiegel (1994) focus on the role of human capital stock on the process of imitation and innovation ${ }^{2}$ capital stock. The human resource situation affects a country's ability to innovate or to catch up with the most advanced countries. Thus, a more appropriate public education expenditure policy maximizes the impact of the growth. However, Krueger and Lindahl (2001) concluded that the significance of the correlation between growth and human capital stocks is not robust because this correlation significance disappears when a number of countries are taken into account. A different approach allows us to take into account the accumulation of human capital as a driver of growth.

Since Musgrave's (1959) pioneering work in establishing a theory of public spending, several approaches have been developed to explain the economic activity of the State, some of them are; the explanations for the growth in state expenditure, the school of public choice and the collective choice theory.

Adolf Wagner (1835-1917) enunciated a "law of increasing extension of public activity": the elasticity of public expenditure with respect to GDP greater than a unit for several industrialized and developing countries. Semedo (2007) recognizes three justifications put forward by the author to explain the frequent value of this elasticity, of which one invokes the need for collective services necessary for the formation of human capital essential for the acceleration of industrialization and growth. The growing need in collective services usually require investments of such importance that only the State can provide them. The Wagner's law is based on the relationships that exist between incomes of citizen to the demand for public goods. The demand for public goods is growing faster than the income of individuals, i.e. the small increase in the income of individuals leads to the allocation of public spending to satisfy the needs for public

\footnotetext{
${ }^{2}$ The highest level of human capital stock leading to the highest rate of adaptation and extension of technical
} progress which leads to growth. 


\section{International Journal of Social Science and Economic Research}

ISSN: $2455-8834$

Volume:05, Issue:12 "December 2020"

goods. The growth in the size of the State is in this perspective, legitimate since it is the result of a citizen's request.

The production of non-market public services is indeed experiencing low productivity gains and can therefore explain the development of public spending. This thesis refers to the law of Baumol (1967), who hypothesizes that the growth of public budgets is more attributable to the growth in unit cost of public production than to the growth in its volume. The growth in this unit cost is a consequence of lower productivity gains in the public sector than in the rest of the economy. In the public services, productivity is growing at a slower rate than that of the market sectors which are largely producers of industrial goods benefiting more from technical progress while nominal wages are aligned with those of the market sectors so that the relative cost of public services tends to increase. The importance of public services multiplies this effect and explains the increasing share of government expenditure as a share of GDP. If the demand for public goods is inelastic to price and the costs of producing public goods increase more than the costs of private goods, the growth in government spending can be explained by a price effect. Baumol (1967) notes that a central part of the increasing state intervention is in the education sector (public expenditure on education) where productivity gains are low or absent. These two theses can explain the growth of public expenditure on education without any linger on their distribution. The school of public choice offers alternative explanations to some extent compensating for this deficiency.

It is widely accepted that the role of government is to provide public goods and services and to contribute to the elimination of negative external economies and that every citizen has a demand for the public good. According to the Median Voter Theorem (MVT), it is the demand of voters, possessing the median income, which determines the level of public spending. This theorem assumes a single public good financed by taxes in proportion to income, the use of the majority rule voting and the distribution of preferences to a single summit. Peltzman (1980), on his part insists on the importance of the "middle voter", i.e., the middle classes who tend to use political mechanisms to increase the production of public goods. In this context, the reduction of social inequalities and the rise of the middle classes, including education is favorable, and constitute an important source of increased public spending on education. The best known application of the Median Voter Theorem is that of Meltzer and Richard (1983) for whom the median voter determines the level of public spending. Their main explanation is that all voters whose income is below the median income will prefer to vote in favor of increasing transfers by the intermediary of social spending. Similarly, if the median voter has productivity lower than the average, he has the advantage to receive income transfer and therefore decide to redistribution, whereas the opposite is true if individual productivity tends towards the average. 


\section{International Journal of Social Science and Economic Research}

ISSN: $2455-8834$

Volume:05, Issue:12 "December 2020"

Stiglitz (1974) analyses the conditions for balancing public expenditure on education in a model of the national economy. He accepts that the equilibrium level results from the preferences of the median voter and compares it to the Pareto optimum. Bearse et al (2005) rather construct a model for determining educational resources through majority voting.

Buchanan and Tullock (1962) put forward the argument of political bargaining' to explain the allocation of public expenditure on education. The main idea is that each interest group can apply for higher benefits or grants for a minority in society. The state does not implement the production of goods separately, but that of the goods requested by some agents than others. But since the funding of these property is distributed among all members of the community, there are many pressure groups which will be constituted and organized so that the State undertakes the production of goods which they need particular benefit. This competition between pressure groups allows for an effective allocation of government resources. The school of public choice has not only been limited to explaining the growth of public spending by the median voter or by the lobbying groups, but also focused on collective choices.

The economic approach allows us to understand the basic principle that the only deriving conditions for budgetary efficiency is not sufficient to confer on the political processes the power to automatically generate the optimal allocation of resources in the public sector. To explain the structure of public spending, a positive collective choice theory is essential. The substantive rationality hypothesis shows that it is impossible to treat the social demand for collective goods as well as private demand. Since the work of Arrow (1970) and Sen (1970), it is possible to define the general interest on the basis of individual preferences. This possibility is based on collective choice procedures which cannot meet all the criteria of democracy. This theory is known as the "theorem" of impossibility". Collective choice theory is based on three modalities: (i) The collective choice can be derived from voting, market or imposed on individuals; (ii) Individual utilities cannot be measured, they can only be classified because it is impossible to measure each individual utilities and to compare them; (iii) and a judicious function of collective preference must meet at least five assumptions that cannot be met simultaneously.

The impossibility theorem states that: "There is no voting method that removes the electoral paradox, neither majority voting nor any system of proportional representation no matter how complex. Arrow (1970) shows that even when the individual preference is only for economic utility and not on moral or ideological choices, the theorem of impossibility is verified; in this case too it is impossible to build a collective preference that satisfies all five hypotheses. The only methods for switching from individual preferences to collective preferences which are satisfied, are not respected and are either imposed or dictatorial ${ }^{3}$. Arrow's theorem is a

${ }^{3}$ The collective choices are coherent in case of a perfect unanimity and when the preferences are uni-modal. 
International Journal of Social Science and Economic Research

ISSN: 2455-8834

Volume:05, Issue:12 "December 2020"

considerable contribution to the understanding of collective choice rules. While it does not allow for a perfect aggregation of individual preferences, it remains the best way of allocating resources. The quantity of collective goods is then neither the result of individual desire nor the result of the demand of the majority because it is most often a coalition of minorities. Although the various public sector theories outlined here can explain social choice and the level of public spending on education, the main criticism is that they do not allow us to determine which allocation of public spending on education would ensure growth. Beyond all these justifications for allocating to human capital investment, a rich empirical literature has looked at the relationship between human capital and economic growth based on the distribution of human capital by educational attainment. Much of this work is based on Lucas' (1988) model of human capital accumulation.

\section{2- Data on public expenditure on education by level of education and growth.}

In Cameroon, the inadequacy of public expenditure allocated to education imposes a financial burden, particularly on poor households. Public spending on education in Cameroon is lower than the average for sub-Saharan Africa and the level planned in the 2013-2020 education sector strategy.

It can be seen in figure 1 below that the greatest increase in public spending on education is observed at the level of primary education, where spending has more than doubled over the previous years. This reflects a clear desire on the part of the public authorities to make up for the accumulated shortfalls and achieve the objectives assigned to this level of education (the increase factor of 1.98 is higher than that of total public expenditure on education, i.e. 1.6486). In spite the strong evolution, public expenditure on basic education, which amounts to 161 billion CFA francs, is still lower than expenditure at the secondary level, which is 202 billion CFA francs. The Ministry of Secondary Education has also seen its expenditure increase over the period from 140 billion CFAF in 2005 to nearly 232 billion CFAF in 2014 (i.e. an increase of $165 \%$ in relative terms). The increase in public spending on higher education is also strong. It increased from 25 billion CFAF in 2005 to 49 billion CFAF in 2014 (i.e. an increase of 196\% in relative value). Overall, the volume of resources for the education sector increases from 239 billion CFAF to 455 billion CFAF in 2014 (a multiplication factor of 1.9 over the period). This increase was disrupted between 2010 and 2011 because having reached 420 billion in 2010, this expenditure fell to 356 billion francs CFA in 2011. 
International Journal of Social Science and Economic Research

ISSN: 2455-8834

Volume:05, Issue:12 "December 2020"

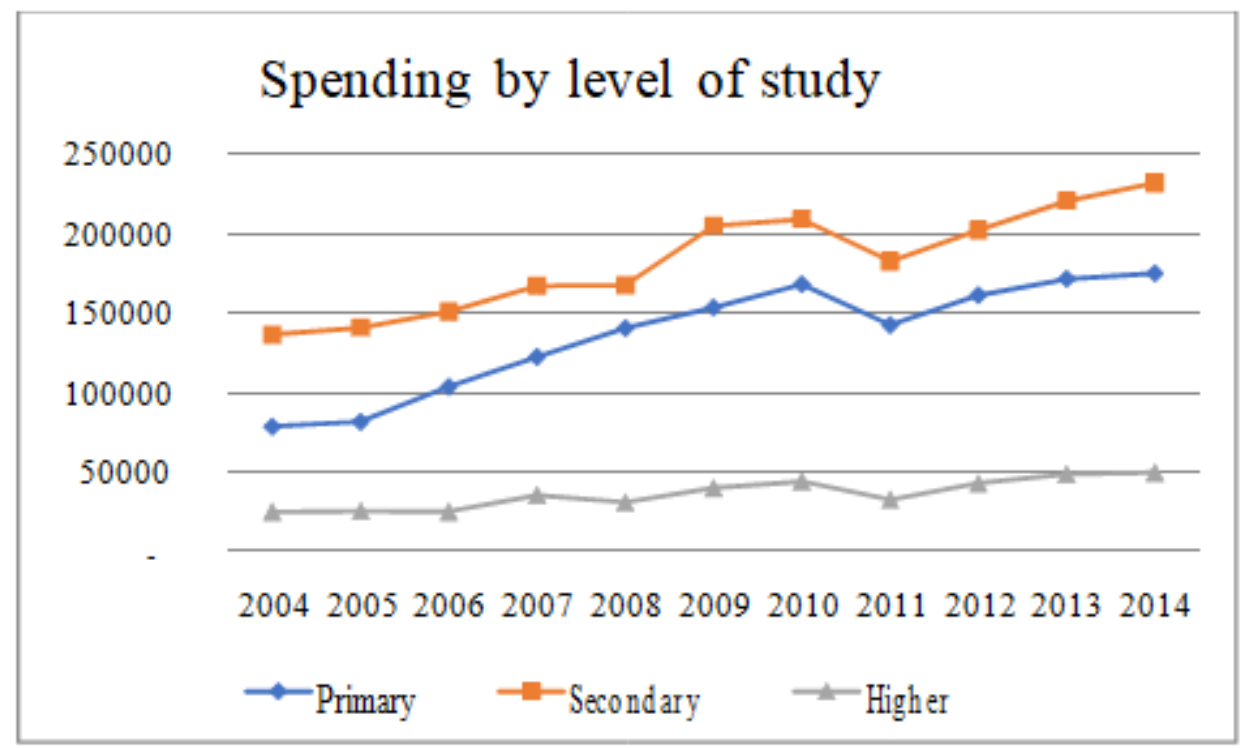

Source: Author from financial law 2004-2014

Poor households with children enrolled in secondary schools report spending up to 13 per cent of per capita household consumption on education. In addition, the proportion of primary school teachers paid by parents rose from 25\% in 2009 to 38\% per cent in the 2015-2016 school year. National education funding comes from three main sources: the State budget, external support from development partners, and parental contributions. Over the period 2014-2016, it was projected that 5 per cent of the total expenditure on education, i.e. $13 \%$ of basic education expenditure, be financed by the development partners. Public expenditure on education is largely directed towards secondary level and this imbalance tends to increase over time. In 2017, Secondary education received 49 per cent of the education budget, while primary education received only 34.1 per cent and the tertiary $10.4 \%$. These overall shares remained stable over ten-years (figure 1), while the number of primary school pupils is important and increase faster than that of the secondary school.

\section{3-1 Economic growth in Cameroon}

Cameroon still called "Africa in miniature" has many opportunities including with its status as the "feeder udder of Central Africa". Formerly, based on the digital economy, has undergone a significant development in the primary sector, i.e. agriculture, fisheries, crafts and mining. The digital economy has evolved significantly. Oil in Cameroon has been spectacular from the very beginning of its activity. In 1986, the economy Cameroon has recorded a strong period of growth over a well-defined period. It is as well as in 1978, the highest value of growth is recorded at 22\% (WDI, 2015). This phase was also marked by a change in the production structure of the economy. At an average over the 1976-1985 period, the industrial sector's share of GDP 
International Journal of Social Science and Economic Research

ISSN: 2455-8834

Volume:05, Issue:12 "December 2020"

increased from almost 8 percentage compared to the previous decade. A few decades later, Cameroon has been a victim of the fall in the international oil price, associated with a devaluation of the oil reserves of the francs CFA against the US dollar which led to a choc of exchange. In 1987, the implementation of a Structural Adjustment Plan led to a reduction in the current expenditure and a significant contraction in public capital expenditure. Social indicators also deteriorated sharply from 1986 onwards, after a long phase of improvement.

Since the 1994 devaluation, Cameroon has been following a trajectory that is characterized by a soft growth. GDP per capita (in constant 2000 dollars) grows on average by $1.4 \%$ per year. This growth is very largely (90\%) private consumption, investment and public consumption contributing on average over a period of 1994-2008, only 19\% and 13\% respectively to GDP growth. Finally, the post-devaluation growth regime is also characterized by the stagnation of poverty. Growth rose from 5.9\% in 2014 to $5.6 \%$ in 2013 in Cameroon. Despite the efforts made, the Cameroon's growth rate remains below the average target of $6 \%$ set in the ECSD, thus being above the averages of CEMAC (2.8\%) and Africa (3.7\%). In Cameroon, the household final consumer price index increased by $0.9 \%$ in 2016, a drop of nearly 2 points compared to 2015 when it stood at $2.7 \%$. This relatively small increase in the general price level is explained by a $3.5 \%$ increase in the prices of hotel and restaurant services and a $3 \%$ increase in alcoholic beverages (INS, 2016).

The poverty rate has decreased by $2 \%$ in 7 years (2007 to 2015) according to EICAM. The poverty line monetary policy set at 931 francs per day and 339715 francs per year (INS, 2016). The Cameroonian economy has evolved in a regional context characterized by security crises and humanitarian in some parts of the country. Insecurity in the far north with "Boko Haram", the conflict in the English-speaking areas in the south-west and north-west. The context of employment in Cameroon remains a current concern. The growth in employment rate was unstable from 2001 to 2005, the 2005 unemployment rate of $4.4 \%$ decreased comparatively to that of 2001, i.e. $7.2 \%$, but the document published by the CIA called World Facebook states an unemployment rate in the order of $30 \%$. 
International Journal of Social Science and Economic Research

ISSN: 2455-8834

Volume:05, Issue:12 "December 2020"

Figure2: Evolution of annual GDP growth rate (\%) in Cameroun

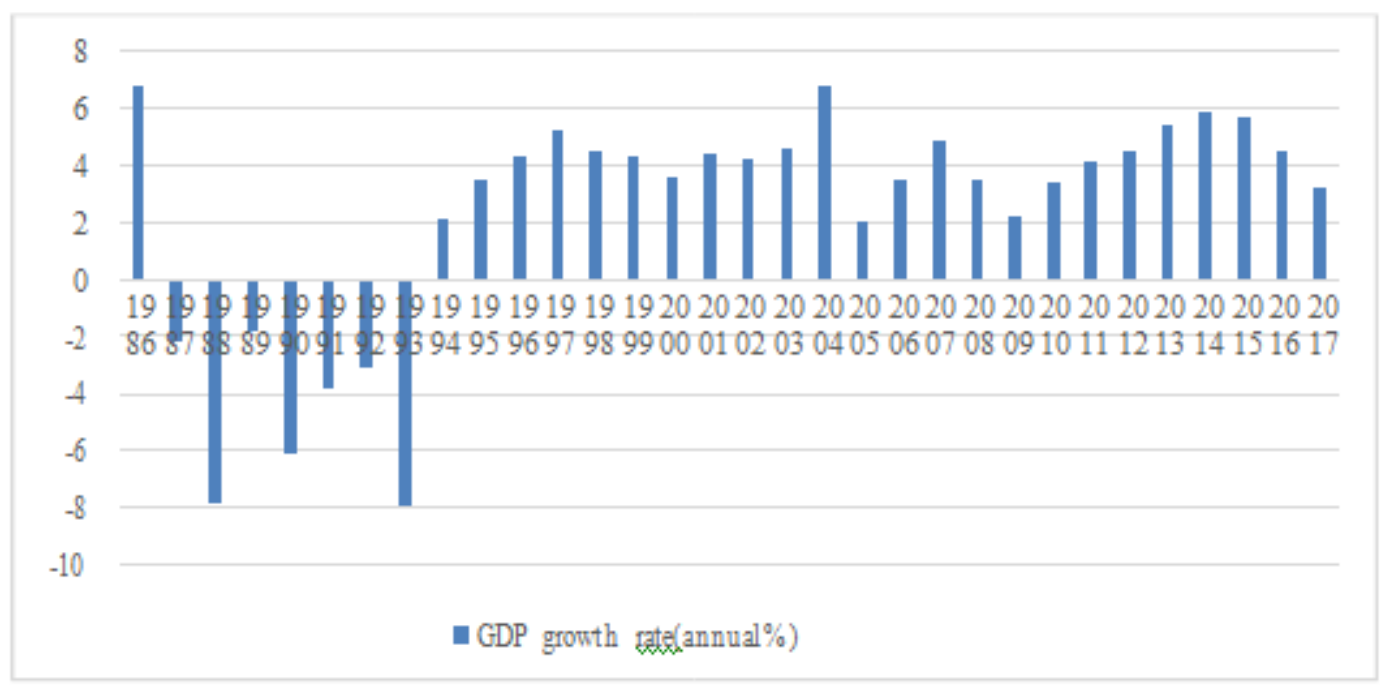

Source: Author with data from WDI, 2017.

The Cameroonian economy remains the most resilient in Central Africa because of its relative diversity; however, it is vulnerable because of its weak growth base and its high exposure to changes in world commodity prices. The achievement of value chain projects in the agrosilvopastoral and fisheries sectors could contribute to strengthening its economic resilience. This requires an improvement in the competitiveness of the economy, including a greater support for transport facilitates, the development of the private sector and regional trade given the country's geographical position.

At the end of this study, it is worth recalling that we extended our concern on the foundations of the relationship between public expenditure on education by level and growth economic. The literature shows that there is a link between public spending of the different educational levels in a country and economic growth. Several countries have invested more on one level of education at the expense of other levels of education which has contributed to reinforcing the adverse effects of high inequality and financial constraint on investment in countries' education systems. Such a policy choice thus contributes to explain why these countries have lower enrolment rates in some cycles than others. Some authors explain the difference in development between States by the difference in the financing of educational human capital. Nevertheless, not all countries with at the same levels of development, each country should finance its education system according to the means at its disposal. The main concern therefore becomes how to allocate these available resources to the different levels of the education system.

4- Methodology for estimating the impact of education expenditure by level of education 
International Journal of Social Science and Economic Research

ISSN: 2455-8834

Volume:05, Issue:12 "December 2020"

This section aims to present the data from the study and to highlight the econometric models used to analyze the impact of public spending on education for different "educational levels" on economic growth in Cameroon. We consider the model of Keller (2006) which puts together several disaggregated educational variables and determines which have a greater impact on growth, contrary to Ben Mimoun (2007) who proceeds by successive steps. However, the work carried out by some authors does not include Cameroon. In their various studies, this gap is filled by empirically analyzing the impact of the disaggregated public expenditure on education on Cameroon's economic growth and in proposing a scheme for the distribution of educational resources.

\section{4-1 Specification of the model, data sources and presentation of variables.}

The fundamental hypothesis that we are trying to verify empirically states that the taking in disaggregation of public expenditure on education allows a better understanding of the impact of education on economic growth. Thus, we follow Musila and Belassi (2004) for the Ugandan case and Keller (2006) for the general case, then we develop a model that integrates several educational variables into the growth equation and through the econometric techniques assess the different contributions of each of the variables estimated.

\section{4-1-1 Econometric specification}

In order to measure the contribution of education to growth, its place in the economy has to be defined at the outset. The production function that relates the gross domestic product, Y, to the factors of production. The introduction of education into an aggregate function can theoretically take several years' different shapes. Although they retain the essential idea that technical progress is not only a special factor, but also an engine of growth, the theories of endogenous growth admit a wide range of sources of productivity growth. One can therefore use, from a theoretical point of view, a set of factors to capture the sources of the growth in a country (Kobou, 2002). This work falls within the theoretical framework of the models of endogenous growth that assign a more central role to the accumulation of human capital as a growth factor (Lucas, 1988). Thus, two variables were selected in a straight line of Keller's (2006) approach: The gross enrolment ratio and public expenditure on education. The model used is based on an aggregate production function under the assumption of the constant returns to scale. The pioneering study of Mankiw, Romer and Weil (1992), taken up by several subsequent studies, assumes that the output of country $i$ is given by:

$$
Y_{i}=K_{i}^{\alpha} \times H_{i}^{\beta}\left(A_{i} L_{i}\right)^{1-\alpha-\beta}
$$




\section{International Journal of Social Science and Economic Research}

ISSN: $2455-8834$

Volume:05, Issue:12 "December 2020"

By normalizing and applying to the cross-sectional data, this model captures differences in growth between countries (Barro and Sala-I-Martin, 1995). The general model is then presented in the following form:

$$
Y_{t}-Y_{t-1}=\alpha+\beta Y_{t-1}+\gamma X_{t}+\mathrm{v}_{t}
$$

Where, $Y_{t-1}$ is the value of the logarithm of the product per capita of the country at date $\mathrm{t}-1 ; X_{t}$ is the vector of all explanatory variables and $v_{t}$ is the random term. The model of Keller (2006), is used to estimate the following equation:

$$
g_{t}=\alpha+\beta \ln Y_{t}+\gamma_{t} X_{t}+V_{t}(3)
$$

With, $X_{t}$ the vector of all explanatory variables considered.

\section{4-1-2 Presentation of variables and data sources}

The annual economic growth rate per capita $(\mathrm{g})$ is the main variable to be explained. In order to explain this variable, we will use several explanatory variables whose names and choices will be explain. In the $\mathrm{X}$ vector of the variables explanatory variables, we find an Edu sub-vector containing the educational variables. We first have the gross enrolment ratio by level of education noted ei ( $\mathrm{i}=1,2$ and 3 ). Gross ratios enrolment are defined as the ratio of the total number of students enrolled in the corresponding level of education and the population of the age group which should be enrolled in school at the corresponding level of education For example, the gross enrolment ratios can exceed 1 and thus exaggerate the number of children in school when students are repeating a grade. We also have public expenditure of education as a percentage of GDP noted pi ( $i=1,2$ and 3) for primary, secondary and tertiary levels. Public expenditure on education as a percentage of GDP is total public expenditure on education expressed as a percentage of the gross domestic product in a given year. Public expenditure on education includes public expenditure on educational institutions (public and private), the education administration and the transfers/grants to private entities (students/households and other private entities).

The remainder of the control variables include indicators generally used in the growth equations. We have, the growth rate of the consumer price index (CPI) the degree of trade openness, Trade, which is the ratio between the sum of exports and of imports on GDP; and finally, the rate of investment in physical capital (I). In detail, equation (3) takes two forms considering that the two specific education measures were selected:

$$
\begin{aligned}
& g_{t}=\alpha_{t}+\beta_{0} \ln Y_{t}+\beta_{1} e_{1 t}+\beta_{2} e_{2 t}+\beta_{3} e_{3 t}+\gamma_{1} I+\gamma_{2} \text { Trade }_{t}+\gamma_{3} \text { Infl }_{t}+V_{t} \\
& g_{t}=\alpha_{t}+\beta_{0} \ln Y_{t}+\beta_{1} \rho_{1 t}+\beta_{2} \rho_{2 t}+\beta_{3} \rho_{3 t}+\gamma_{1} I+\gamma_{2} \text { Trade }_{t}+\gamma_{3} \text { Infl }_{t}+V_{t}
\end{aligned}
$$


International Journal of Social Science and Economic Research

ISSN: 2455-8834

Volume:05, Issue:12 "December 2020"

With the exception of the Infl variable, the sign predicted by economic theory is positive for all the other variables. Using the sub-vector Edu (ei, and pi), we will test the contribution of education on economic growth in Cameroon. The expected sign is positive for these two indicators. We expect a positive sign for the coefficients of the variables related to openness trade(trade), and investment (I). However, the rate of inflation theoretically has a negative effect on growth, hence the sign of the Infl variable could be negative. Data on the gross enrolment ratio are taken from the UNESCO database. With regard to public spending on education, we have made use of the finance acts and Cameroon's financial and economic reports (1986-2016). Data on other indicators as well as GDP per capita are provided by the World Bank's recent database World, WDI, 2017.

\section{4-1-3- Central trend characteristics.}

Table 1: Characteristics of central tendency and dispersion of the series of variables

\begin{tabular}{|l|r|r|r|r|r|}
\hline Variables & Obs & Mean & Std. Dev. & Min & Max \\
\hline gt & 31 & 2.292788 & 4.149363 & -7.932066 & 6.780956 \\
\hline e1 & 31 & 102.5953 & 13.67559 & 82.67442 & 124.2468 \\
\hline e2 & 31 & 34.1484 & 11.87651 & 22.83847 & 60.69015 \\
\hline e3 & 31 & 6.675715 & 4.939393 & 2.156987 & 19.20137 \\
\hline p1 & 31 & 1.09035 & 0.117009 & 0.7330345 & 1.288399 \\
\hline p2 & 31 & 1.223926 & 0.3310482 & 0.7163746 & 1.86471 \\
\hline p3 & 31 & 0.4156416 & 0.206843 & 0.2165784 & 0.9541 \\
\hline Infl & 31 & 2.795945 & 3.108576 & -3.206555 & 13.1405 \\
\hline Trade & 31 & 46.37872 & 8.453105 & 26.45271 & 61.9796 \\
\hline I & 31 & 21.29773 & 2.542759 & 14.30539 & 24.79572 \\
\hline Source Aut & & & & & \\
\hline
\end{tabular}

Source: Author 


\section{International Journal of Social Science and Economic Research}

ISSN: $2455-8834$

Volume:05, Issue:12 "December 2020"

Table 1 above groups together all the central tendency characteristics. The reading of this table shows that Cameroon's average gross enrolment ratios during the period of study are of the order of $102.59 \%$ for primary education, $34.14 \%$ for secondary education and $6.67 \%$ for higher education. We note that the gross enrolment rate in higher education is very low, and requires the government to put in place policies to increase this rate for it will need human resources coming out of higher education and ready to be used.

Cameroon's average public expenditure on education over the same period is estimated at $1.09 \%$ of GDP for primary education, $1.22 \%$ of GDP for secondary education, and finally $0.41 \%$ for higher education. The average inflation rate is $2.79 \%$. We can note that it is below the standard set in the CEMAC Zone which is $3 \%$. In terms of is of the commercial opening, its average rate is $46.37 \%$ for the period. The reason for this high rate of trade opening is that Cameroon has a good relationship with several countries such as: China, which has become the first partner with whom Cameroon trade but also the European Union with the economic partnerships agreements and many other countries. The country's investment rate is rising on average of $21.29 \%$. The investment rate is low because the private sector, which has to carry the investment, has difficulty in accessing bank credit.

\section{5- Discussion of the results}

The results of the Ordinary Least Squares estimates show that the gross rates of enrolment at primary, secondary and higher levels all improve the quality of education growth in Cameroon's GDP/capita. If there is a $1 \%$ change in the gross rate of primary school enrolment, GDP/capita will increase by $0.013 \%$. For secondary education, a $1 \%$ change in the gross enrolment ratio increases GDP/capita by $0.004 \%$. For higher education, a $1 \%$ changes in the rate of schooling increases the GDP/capita by $0.003 \%$. The results of a negative impact of public expenditure on primary education on economic growth are consistent with less of the previous studies mentioned above. In fact, the results are in line with studies such as Abbas (2001), Villa (2005) and Shaihani et al (2011). Such as Romer (2001) has noted, primary education may not produce short-term results in the economy, but have indirect long-term effects on the economy. It is therefore understandable that despite the negative impact of public spending on primary education, continued support is needed for this level which is the base for other levels of education.

However, public expenditure on secondary and higher education has a positive effect on Cameroon's economic growth. These overall results are contrary to the research by Gemmell (1996), Mingat and Tan (1996) and Petrakis and Stamatakis (2002), which have concluded that primary education affects less developed countries more, while the growth in the more developed countries depends mainly on higher education, and secondary. This result clearly indicates that 


\section{International Journal of Social Science and Economic Research}

ISSN: $2455-8834$

Volume:05, Issue:12 "December 2020"

the primary education advocated by international institutions is not the solution for the economic growth and development of developing countries such as Cameroon.

\section{Conclusion and Recommendations}

At the end of this study, which aimed to evaluate the impact of public expenditure by level of study on growth in Cameroon? We are entitled to say that the link between the two concepts is real, at least within the limits of our study sample. Having econometrically tested the distribution of public expenditure on education in the different levels of education, the results show that public expenditure on education allocated to the secondary and higher levels has a favorable effect on the economic growth of the country, but this effect is significant at a $1 \%$ level of public expenditure on secondary education. This result indicates that an additional allocation of public resources at the secondary and higher levels leads to an increase in the rate of economic growth in Cameroon. This can be explained by the fact that human resources from these educational levels are used for production in the economy. For example, at the higher level, young graduates are recruited in enterprises where they will contribute to production and thus contribute to the country's economic growth.

However, public spending on primary education has a negative but not significant impact. This can be explained by the fact that human capital from primary education only begins to be productive in the long term. Moreover, all students who go to primary school do not reach the end of the primary curriculum. Some drop out without reaching secondary level. This explains why public spending on primary education does not improve the growth rate of GDP/capita in Cameroon.

These results are contrary to those of Keller (2006), who finds only a positive impact for public spending on education at the primary level in developing countries development. The difference in his results with ours may be due to the size of the company, the sample or the fact that it works with a panel of countries, but we only work on Cameroon. With a high primary school enrolment and life expectancy since schooling is around 10 years old, it seems essential to allocate more spending to the education system at the primary level and to maintain the level of public spending on secondary education to accommodate students who have passed at the primary level. This finding is consistent with the work led by Romer (2001) who notes that primary education may not yield short-term results in the economy, but that it indirectly has long-term effects on it. Since primary school is the first level of education and the basic level, it is very important for the other two levels of education. However, Aghion and Cohen (2004) defend the hierarchical nature of any system of education. Indeed, for effective investment in graduate education, it is important to have solid investments in the elementary cycles and it is indispensable to have individuals to successfully complete lower cycles of schooling. This 


\section{International Journal of Social Science and Economic Research}

ISSN: $2455-8834$

Volume:05, Issue:12 "December 2020"

creates a dynamic dependence of graduate-level efficiency and skill levels on the stock of knowledge formed in the undergraduate cycles. The proposed budget reallocation would ensure a better internal redistribution within the system education, because in terms of equity, analysis of structural distribution shows that $10 \%$ the most educated population accounts for $38 \%$ of public spending on education. Studies have shown that the reallocation of public spending on education also offsets to an extent, household income inequality (Naito and Nishida, 2012). As a whole and for each cycle, the public education service is less unevenly distributed between socioprofessional categories than household income. This trend is very much shared in many developed countries, hence the importance of introducing this aspect in developing countries where the situation is quite opposite.

Our study makes a number of economic policy recommendations: The Cameroonian authorities are therefore invited to take vigorous action in various areas: Reforms in education sector should resolve the difficulties that are emerging in the education sector in an efficiency and fairness manner. The authorities are called upon to better manage the resources allocated to education. They should rationally distribute funds among the different levels of education. Culturally, many barriers have to be overcome by the populations under the leadership of the authorities. The latter should make the population more aware of the benefits of education, especially for women.

However, some shortcomings of the study should be highlighted. The study merely recommends a qualitative and quantitative improvement in the supply of educational services without seeking to make a return on investment in education at both the individual and social levels. Moreover, our model has its origins in Lucas's (1988) endogenous growth model, and it seems that the assumption of linearity of returns to education is unrealistic, as noted by Aghion and Howitt (1998, p.330). These criticisms thus call into question our basic model.

\section{References}

Adiqa, K. (2011), « Role of University Education in Poverty Alleviation in Pakistan ».Interdisciplinary Journal of Research in Business, 1 (7), 30-38.

Aghion P. et Howitt P. (2010), «L'économie de la croissance », Economica.

Arrow, K. (1962), « The economic implications of learning by doing», Review of Economic Studies, 29 (3), pp.155-173.

Banerjee, A., Dolado, J., and Smith, G. (1986), «Exploring equilibrium relationships in econometrics through static models: some Monte-Carlo evidence ». Oxford Bull. Econ.

Barro R.J. et Sala-i-Martin X. (1995), «Economic Growth», New York: McGraw-Hill. 
International Journal of Social Science and Economic Research

ISSN: 2455-8834

Volume:05, Issue:12 "December 2020"

Baumol (1967), «Macroeconomics of unbalanced growth: The Anatomy of Urban Crisis ». The American Economic Review, Vol 57. №3 p.415-426.

Becker G., et Tomes N. (1986), «Human capital and the Raise and Fall of the Families», Journal of Labor Economics, 4, pp1-39.

Benhabid., et Spiegel M.M., (1994), «The role of human capital in economic development: evidence from aggregate cross-country data», Journal of Monetary Economics 34.

Berthélemy, J. et Arestoff, F., (2002), « Les stratégies d'éducation et le développement en Afrique» ; in L'éducation, fondement du développement durable en Afrique, pp : 95-132 ; PUF, 1ère édition, Paris, juin.

Dessus S. (2000), « Capital humain et croissance : le rôle retrouvé du système éducatif », Économie publique/Public economics, $\mathrm{n}^{\circ} 06$.

Gemmell, N. (1996), «Evaluating the impacts of human capital stock and accumulation on economic growth: some new evidence», Oxford Bulletin of Economics and Statistics, 58, 9-28.

Granger, C.W.J. (1988), «Some recent developments in the concept of causality», Journal of Econometrics, 39, 199-211.

Griffith, R., Redding, S., Van, Reenen, J. (2004), « Mapping the two faces of R\&D : Productivity growth in a panel of OECD industries ». The Review of Economics and Statistics, 86 (4), 883-895.

Hanushek, E.A., (2016), «Will higher education improve economic growth? ».Oxford Review of Economic Policy 32, no. 4: 538-552.

Hanushek, E. A., and Woessmann, L. (2012b), «Schooling, educational achievement, and the Latin American growth puzzle».Journal of Development Economics 99, no. 2 (November): 497512.

Howitt, P. (2004), «Health, human capital and economic growth: a Schumpeterian perspective. In Health and Economic Growth: Findings and Policy Implications», G. Lopez-Casasnovas, B. Rivera, and L. Currais, eds. Cambridge, MA: MIT Press.

Johansen, S. (1991), « Estimation and hypothesis testing of cointegration vectors in gaussian vector autoregressive models ». Econometrica, 59, 1551-1580.

Keller K.R.I. (2006), « Investment in Primary, Secondary, and Higher Education and the Effects on Economic Growth », Contemporary Economic Policy, vol. 24, n 1, pp. 18-34. 
International Journal of Social Science and Economic Research

ISSN: 2455-8834

Volume:05, Issue:12 "December 2020"

Krueger, A. and Lindahl M., (2001), «Education for Growth: Why and For Whom? », Journal of Economic Literature, 39, 1101-1136.

Kobou G. (2002), « Les sources de la croissance économique au Cameroun », Economie et Gestion, vol. 3, $\mathrm{n}^{\circ}$ 2, pp. 53-71.

Leker L. etPonthiere G. (2012), «Education, Life Expectancy and Family Bargaining: The Ben-Porath Effect Revisited », PSE Working Papers n2012-32. 2012. <Halshs-00715104>

Loening, J. et al., (2001), «Effects of education on economic growth: Evidence from Guatemala» MPRA Paper 23665, University Library of Munich, Germany.

Lucas, E. (1988), “On the mechanics of economic development» Journal of Monetary Economics, 22, 342.

Mankiw, N.G., Romer, D., Weil, D.N., (1992)« A contribution to the empirics of economic growth ». Quarterly Journal of Economics 107, 407 - 437.

Meltzer A. et Richard S. (1983), « Tests of a rational theory of size of government », Public choice, vol41.

Mincer J. (1958), «Investment in human capital and personal income distribution», Journal of Political Economy, 66 (4), pp. 281-302.

Musila J. and Belassi W. (2004), «The Impact of Education Expenditure on Economic Growth in Uganda: Evidence from Time Series Data»The Journal of Developing Area, Vol.38, No.1,

Naito et Nishida (2012), « The Effects of Income Inequality on Education Policy and Economic Growth » Theoretical Economics Letters, 2, 109-113.

Nelson R.R. et Phelps E.S., (1966), «Investment in Humans, Technological Diffusion, and Economic Growth»,The American Economic Review, Vol. 56, No. 1/2. pp. 69-75.

OCDE (2018), « Dépenses publiques d'éducation (indicateur) ». Doi : 10.1787/89d5a431-fr Peltzman S. (1980), « The growth of government », Journal of Law and Economics, vol 23, no2.

Pereira, J., and Aubyn. M. (2009), "What Level of Education Matters Most for Growth? Evidence from Portugal,” Economics of Education Review, 28(1), 67-73.

Philips, P.C. et Perron. P. (1988), « Testing for a Unit Root in Time Series Regression», Biometrika, 57(2), 335-346.

Pritchett L. (2001), «Where Has All the Education Gone? », The World Bank Economic Review, vol. 15, n³, pp. 367-391. 
PNUD (2018), «Rapport Mondial sur le développement humain », Paris, pays multiples, Economica, La découverte, 2015-2018 Paris : PNUD.

Psacharopoulos, G. (2006), «The Value of Investment in Education: Theory, Evidence and Policy». J. Educ. Finance 32, 113-136.

Roemer J.E. (1998), “Theories of distributive justice”, Cambridge: Harvard University Press.

Romer, D. (2001), “Advanced macroeconomics,” 2nd edition, New York: McGraw-Hill.

Schumpeter, J. (1950), « Capitalism, Socialism and Democracy ». Harper and Row.

Schultz T.W. (1962), « Reflections on Investment in Man », Journal of Political Economy, vol.70,pp.1-8.

Semedo G. (2007), «L'évolution des dépenses publiques en France : loi de Wagner, cycle électoral et contrainte européenne de subsidiarité », L'Actualité économique, vol. 83, n², pp. 123.Sen, A. (2000), « Un Nouveau Modèle économique. Développement, Justice, Liberté ». Paris :OdileJacob.

Shaihani, M.et al. (2011), «Long Run and Short Run Effects on Education Levels: Case in Malaysia », International Journal of Economic Research, 2(6), 77-87.

Sianesi, B., and Reenen. J. (2003), «The returns to education: macroeconomics », Journal of Economic Surveys, 17, 157-200.

Sims, C. A., Stock J., and Watson (1990), «Inference in Linear Time Series Models with some Unit Roots », Econometrica, 58, 113-144.

Solow, R. M. (1956), «A Contribution to the Theory of Economic Growth », Quarterly Journal of Economics, 70(1), 65-94.

Stiglitz J.E (1974), «The demand for education in public and private school systems», Journal of Public Economics, 3, pp349-385.

Vandenbussche.,Aghion P., Meghir c., (2006), «Growth distance to frontier and composition of human Capital », Journal of Economy Growth, pp 11. 